\title{
RECONSTRUCTING AIRPORT PAVEMENTS USING THE TECHNOLOGY OF PREFABRICATED CONCRETE SLAB
}

\section{NAPRAWA NAWIERZCHNI LOTNISKOWYCH Z WYKORZYSTANIEM TECHNOLOGII BETONOWEJ PLYTY PREFABRYKOWANEJ}

DOI: $10.30540 /$ sae-2020-012

\begin{abstract}
A bstract
This article presents the construction and technical concept for the use of an innovative repair of the airport pavement. It consists in embedding a prefabricated concrete slab in place of the excessively degraded surface of the existing slabs. In addition, the introduced technology of connecting adjacent panels together increases the spatial stiffness of the entire functional element and significantly increases the load-bearing capacity of the pavement. The results of laboratory and field tests presented in the article confirm the effectiveness of the technology used. As a result, the application of the reconstructing technology ensures the safety performance of aircraft operations at airports facilities.
\end{abstract}

Keywords: prefabricated slab, airport, load capacity, airport pavements, cement concrete

\section{Streszczenie}

W niniejszym artykule przedstawiona została konstrukcyjno-techniczna koncepcja dotyczaca zastosowania nowatorskiej naprawy nawierzchni lotniskowej. Polega ona na wbudowaniu prefabrykowanej płyty betonowej w miejscu nadmiernie zdegradowanej nawierzchni ptyt istniejących. Ponadto wprowadzona technologia połaczenia ze soba plyt sasiednich zwiększa przestrzenna sztywność całego elementu funkcjonalnego oraz znaczaco wptywa na wzrost parametru nośności nawierzchni. Przedstawione $w$ artykule wyniki przeprowadzonych badań laboratoryjnych i poligonowych potwierdzaja skuteczność zastosowanej technologii. W rezultacie stosowanie przedmiotowej technologii napraw zapewnia bezpieczne wykonywanie operacji statków powietrznych na obiektach lotniskowych.

Słowa kluczowe: płyta prefabrykowana, lotnisko, nośność, nawierzchnie lotniskowe, beton cementowy

\section{INTRODUCTION}

The safety of air operations depends largely on the technical condition of the airport pavements used. Most of the airport pavements in Poland were made in the cement concrete technology, which should meet a number of requirements specified in the relevant normative documents. First of all, cement concrete intended for the driving layer of the pavement should ensure safe transfer of loads generated by aircraft and thermal loads to the ground [1].

Airfield pavements made in cement concrete technology can be divided into three basic groups, according to their current operating status. These groups include: newly built surfaces that are under construction, used surfaces that meet all standard requirements and surfaces that require remedial actions. In the case of the last group, we are talking about objects that require special attention, as a significant number of damage may directly affect the safety of air operations.

The construction and technical concept described in this article, related to the use of an innovative repair of the airport pavement, consisting in the incorporation of a prefabricated concrete slab, is intended to recreate the structural arrangement of the pavement with the assumed physical and mechanical properties. In addition, the technology used to connect the existing adjacent slabs with each other creates a 
new construction quality and provides load capacity at least comparable to that of adjacent airport slabs. The results of tests and studies presented in the article clearly confirm the legitimacy of using the abovementioned technology.

\section{ANALYSIS AND REVIEW OF THE TECHNOLOGY OF PREFABRICATED CONCRETE SLABS USED AT AIRPORTS IN POLAND AND AROUND THE WORLD}

\subsection{United States of America (USA)}

The use of precast concrete slabs in the US, both in road and airport infrastructure, has been broadly covered in the Strategic Highway Research Program 2 (SHRP2). The main goal of the project was to create methods and technologies for the renovation of road surfaces, while maintaining the least inconvenience for users in a clearly defined time regime. The basic technology on which the team of experts worked was the PCP (Precast Concrete Pavement) technology [2] based on the use of prefabricated concrete slabs for quick renovation of the surface. The analyses and experiments carried out by SHRP 2 were based on the creation and application of a technology that would be able to effectively meet the following conditions:

- production of precast concrete elements will ensure adequate strength and durability of concrete;
- the production techniques and equipment used will ensure the efficiency of PCP systems;

- connections of prefabricated slabs will ensure effective load transfer;

- the slabs used will be thinner than concrete built in place by using prestressing elements.

Over the years of using PCP technology, the system has been divided into two basic categories:

I. Intermittent repairs of concrete pavements consisting in carrying out local, single repairs of the surface with the use of prefabricated concrete slabs. Repairs were carried out both in the case of whole degraded and cracked boards as well as damage to board joints or corners.

II. Continuous application consisting in carrying out repairs of the entire section of the pavement by installing prefabricated panels on its successive parts.

An example of the use of the PCP precast concrete slab technology at the airport was the incorporation of prefabricated elements on the taxiway at La Guardia International, New York in 2000 (Fig. 1). The task was to perform two test sections with a total length of $61 \mathrm{~m}$. Reinforced concrete slabs with dimensions of $3.8 \times 7.6 \mathrm{~m}$ were used in both sections, $400 \mathrm{~mm}$ thick prefabricates were used on the first section, and

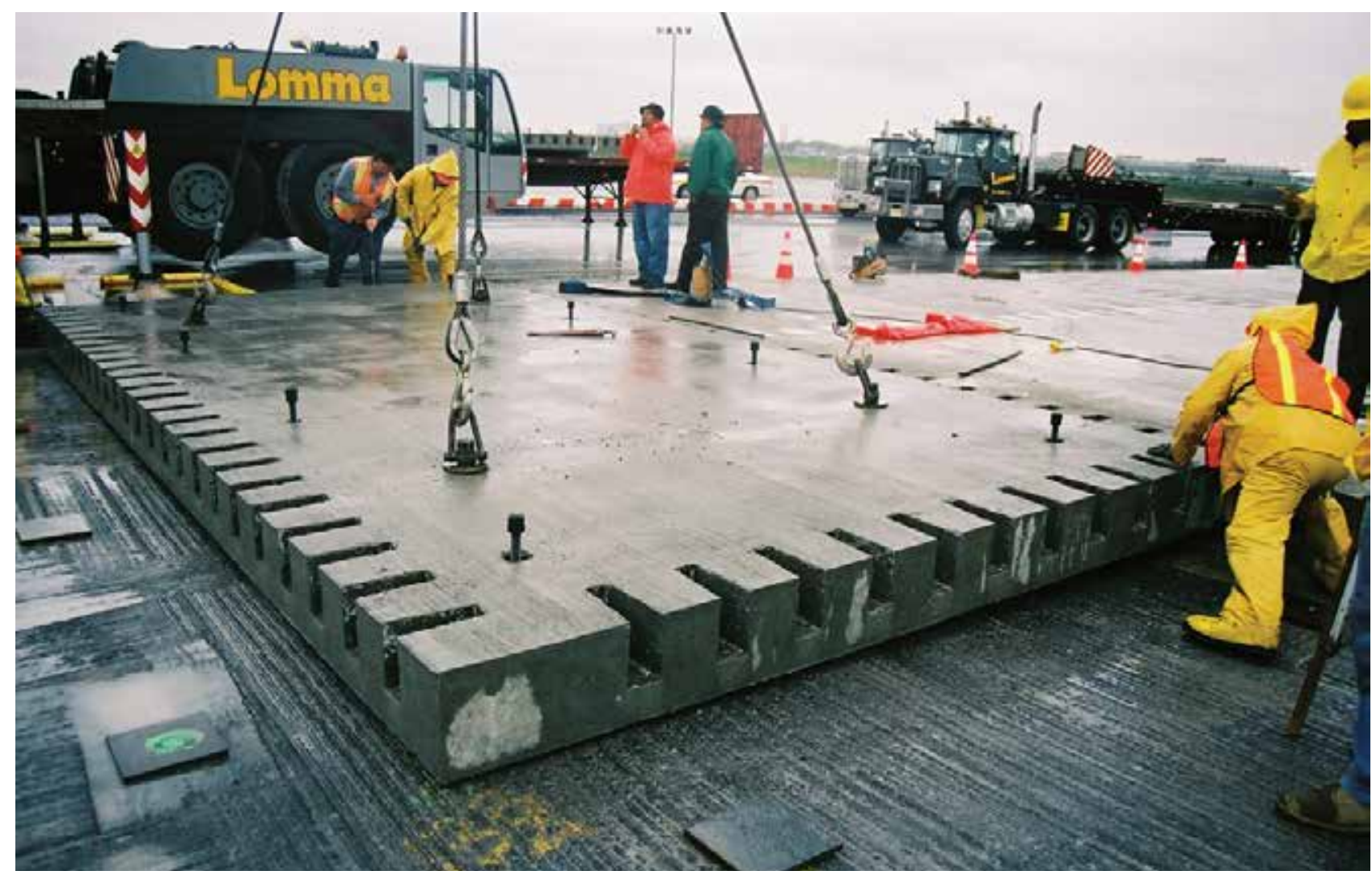

Fig. 1. Prefabricated PCP concrete slab used at La Guardia International airport in New York [2] 

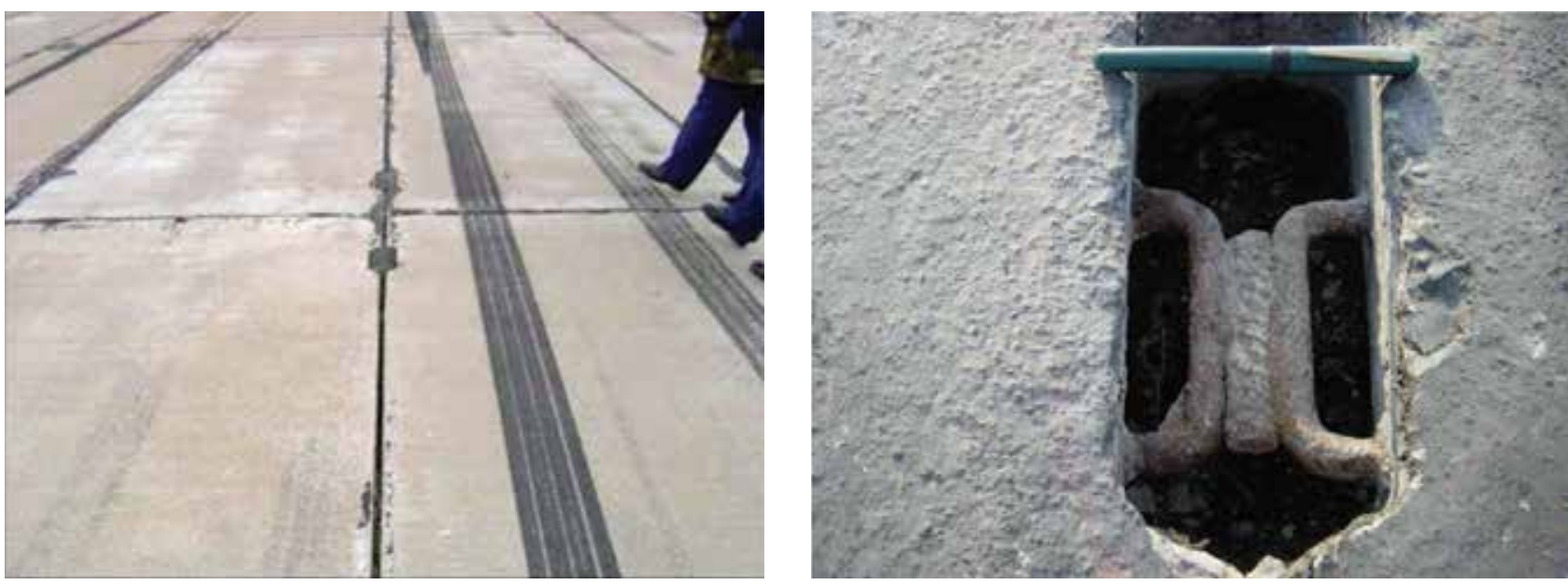

Fig. 2. Prefabricated slabs used in the USSR (on the left airport slabs, on the right-the technique of connecting staples) [1]

$300 \mathrm{~mm}$ thick on the second section. A characteristic feature of the technology used was the use of special screws, which were responsible for the correct height adjustment of the plates. Moreover, there was a gap under the boards (from $13 \mathrm{~mm}$ to $25 \mathrm{~mm}$ ), which was filled with a prepared cement mortar. In addition, the plates were equipped with specially designed pockets for the use of dowels.

It is worth noting that numerous experiments with the use of prefabricated concrete slabs in the USA have led to the development of several innovative pavement repair systems based on the PCP technology. This group includes Fort Miller SuperSlab System, Kwik Slab System, Michigan System or the aforementioned La Guardia International Airport System, which have become rational methods of quick and effective surface repair.

\subsection{Union of Soviet Socialist Republics (USSR)}

Since the 1960s, the Union of Soviet Socialist Republics has pioneered the use of the technology of prefabricated concrete panels [1]. The technology was applied based on reinforced slabs, predominantly on the roads in the north of the country due to the economically attractive area (Fig. 2). The essence and innovation of the prefabrication technology used in the USSR was electrothermal compression by stretching longitudinal bars, the use of thinner plates and a unique method of joining plates. Slabs as standard, it had dimensions of $2 \times 6 \mathrm{~m}$ or $2 \times 4 \mathrm{~m}$. The slabs were $160,180,200$ or $220 \mathrm{~mm}$ thick. A characteristic feature of the method was the use of welded clamps installed along the longer edge of the plate. If the staples were more than $4 \mathrm{~mm}$ apart, a special rod was used, the diameter of which was three to four times larger than the gap between the staples.

\subsection{Poland}

The seventies of the twentieth century can be described - as the beginning of the use of prefabricated slabs in the form of pre-stressed slabs (LWS) in Poland (Fig. 3). Pre-stressed slabs were used primarily at military airfields. The standard dimensions of the board are: length $6.0 \mathrm{~m}$, width 2.0 $\mathrm{m}$ and thickness $140 \mathrm{~mm}$. A characteristic feature of the LWS panels were their connecting elements, namely the steel clamps that were placed in properly formed slab sockets before concreting. The clamps were placed in pairs on the front and side surfaces of the panel, creating characteristic linear joints that ensured sufficient cooperation between the plates [1, $3]$. The clamps were welded together and the quality of this weld largely determined the effectiveness of the connections between the individual boards.

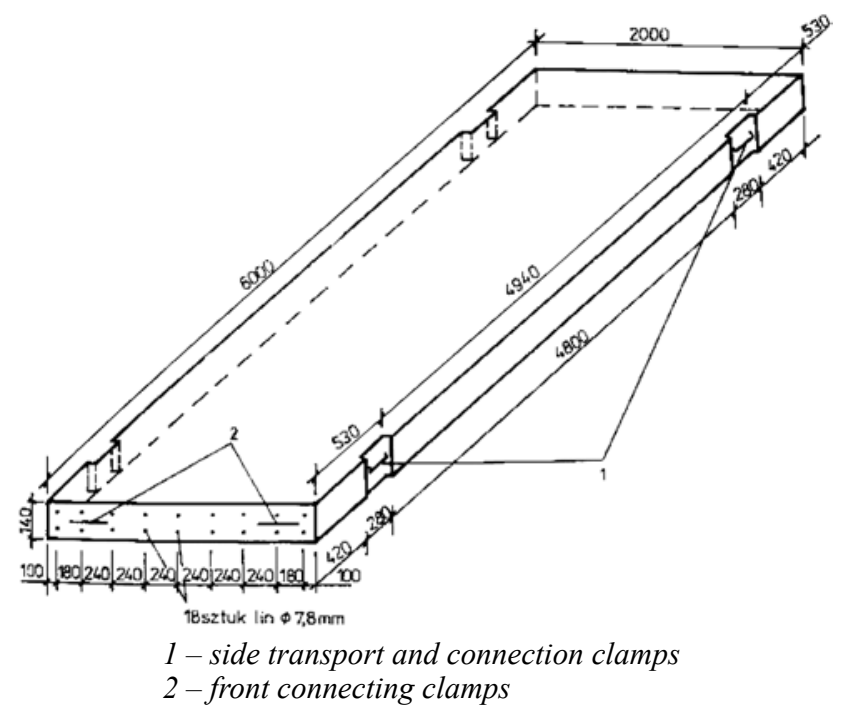

Fig. 3. Airfield pre-stressed slab (LWS) [1] 
The concrete used at that time for the production of LWS slabs was B-40 class concrete. Concrete of this class guaranteed the transfer of high prestressing loads and direct benefits in the form of the reduction of the concrete cross-section in the pavement and thus the weight of the entire structure [1]. In addition, concrete had such properties as:

- transferring significant compressive loads across the entire section of the slab;

- high resistance to delamination in the tendon anchoring zone;

- transferring significant tensile stresses generated by aircraft.

For prestressing reinforcement, non-prestressing reinforcement and auxiliary reinforcement, steel of different properties and purpose was used. LWS boards could be used regardless of the season and weather conditions. The slabs constituting the airport pavement were laid on a properly prepared substrate, maintaining the condition of full adhesion of the slabs to the substrate.

\section{ANALYSIS AND ASSESSMENT OF THE TECHNICAL CONDITION OF AIRPORT PAVEMENTS AND ITS IMPACT ON SAFETY}

Airports where air operations are performed by aircraft used by both civil and military aviation, especially those with jet propulsion, require design and then construction of pavements meeting the highest quality standards [4]. In domestic conditions, the most common type of pavement are pavements made in the cement concrete technology.

Meeting the quality standards means first of all ensuring good adhesion of aircraft wheels to the surface, properly designed and made longitudinal and transverse slopes for effective water drainage, frost resistance and resistance to de-icing agents, as well as high compressive and bending strength. The airport pavement should also provide adequate loadbearing capacity, evenness, roughness and durability, especially for the subsurface layer.

In order to meet all of the above characteristics, it is necessary to constantly monitor and assess the condition of airport pavements, and in the event of damage - to take immediate action. One of the main conditions for maintaining the airport pavement in a condition that does not endanger the aircraft is the knowledge of the current technical condition of the pavement used [5].

Due to fatigue and destructive processes occurring as a result of the impact of traffic and the environment, the cement concrete causes damage that poses a real threat to aircraft. Such damage should be subject to a detailed inventory for each functional element at the airport, and then take immediate corrective action. The most common method of inventorying damage is the visual method consisting in direct inspection on the site, during which damage data is recorded on previously prepared sleepers. The inventory includes both newly created damage and those that have already been repaired. Thanks to this approach, it is possible to determine the overall rate of degradation of the facility, ongoing monitoring of repairs and assessment of their effectiveness [4]. In practice, concrete slabs with dimensions of $5 \times 5 \mathrm{~m}$ are most often subject to inventory. An additional element facilitating the inventory of damage is their division into surface damage (e.g. flaking, hairline cracks), point damage (e.g. chipping, cracks in the corners) and line damage (e.g. cracks, losses of sealing compound in expansion joints) [1].

Technical diagnostics performed as part of the airport pavement condition assessment should include methods and procedures that will consist of [1]:

- a list of tests and measurements having a direct and indirect impact on the technical condition of the pavement;

- characteristics of research methodology and tools for their analysis;

- a list of tools and measuring devices;

- description and characteristics of the traffic taking place on a given surface;

- all repairs that have been carried out so far.

The final assessment of the pavement condition should clearly indicate whether a given infrastructure object meets the requirements and can be operated, or whether it is necessary to take measures to introduce restrictions or close it [22]. For this purpose, a threelevel scale for assessing the degree of pavement damage is used (Fig. 4):

- level I - applies to new, renovated surfaces and those that will not require renovation works in the next 5 years (no actions are taken);

- level II - also known as a warning level, where it is necessary to perform additional detailed studies to determine what corrective actions are required;

- level III - defined as critical, where it is necessary to take immediate actions to improve the condition of the pavement, and in some cases to exclude a given object from use. 


\section{Assessment of the degree of damage to the pavement}

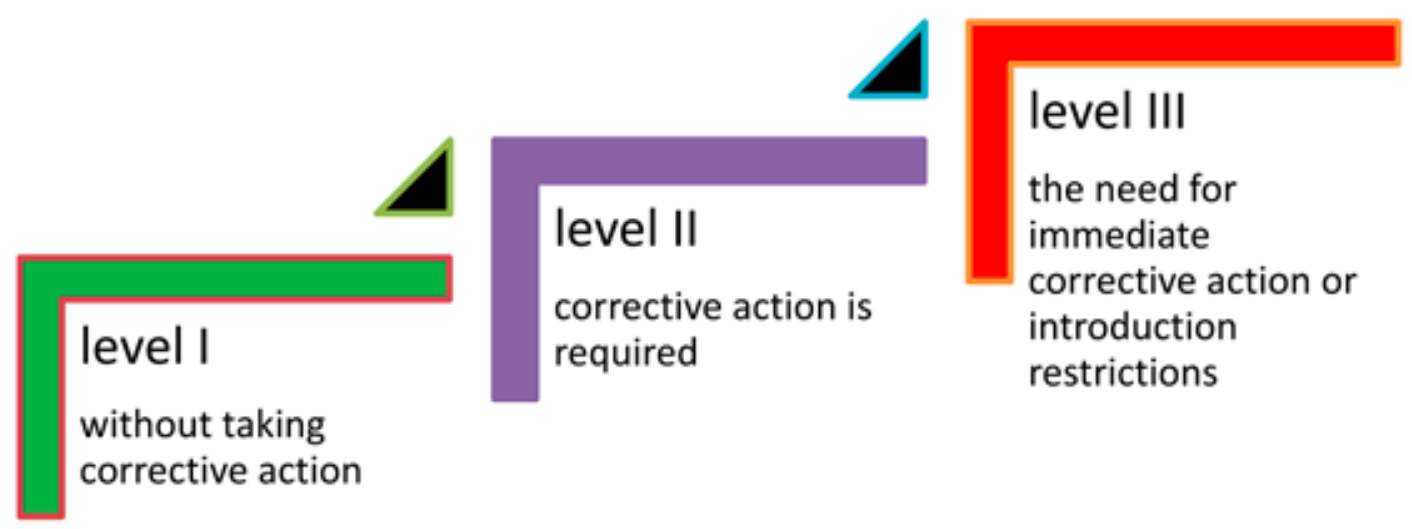

Fig. 4. Assessment of the degree of damage to the pavement

Airport pavements are a probabilistic system in which certain behaviours and changes in the technical condition cannot be clearly predicted and determined [6]. In this case, we can only test the appropriate level of confidence in the events that occur in the pavement structure.

In the process of diagnostics of airport pavements, first of all, attention should be paid to the continuity of its operation, which is a necessary condition for the functioning of the airport. Any renovation works should be understood as local repair works or replacement of the entire element, which in both cases will lead to the recovery of the operational properties of the pavement. In some cases, when the airport pavement is subject to several dozen years of use, and the scale of damage is so large that single, local repairs turn out to be ineffective, then it is necessary to carry out a major renovation of the pavement. The appropriate selection of diagnostics of the airport pavement is a key element, the detailed analysis of which leads to the determination of the predicted condition of the pavement, which in turn makes it possible to safely perform air operations [17].

\section{TECHNOLOGY OF REPAIRING THE AIRPORT PAVEMENT USING A PREFABRICATED CONCRETE SLAB}

The long-term exploitation period of concrete airfield pavements leads to numerous damages, which may constitute a very real threat to air operations [7]. In the event that the damage is related to the destruction of entire fragments of concrete slabs, and the repairs carried out so far turn out to be ineffective, it has become necessary to introduce a repair technology consisting in replacing the entire slab or its part. It should be added that the time of decommissioning a given object should be as short as possible due to the very large financial losses incurred by the airport in the event of disabling certain parts of the infrastructure, especially the runway, which is a key element of air operations. The introduced technology of prefabricated airport slabs assumes the reconstruction of damaged airport pavements and the reconstruction of operational parameters at least as present on the adjacent slabs. At the same time, the duration of the entire repair task does not exceed 5 hours [8].

\subsection{Characteristics of the prefabricated airport slab}

The prefabricated concrete slab, which is prepared in advance in the prefabrication plant, has dimensions: $2.50 \times 5.00 \mathrm{~m}$ and a thickness of $0.24 \mathrm{~m}$ (Fig. 5). The slab is made of concrete class $\mathrm{C} 35 / 45$ and in its crosssection it has the following main reinforcement made of steel class AIII:

- top reinforcement in the form of ribbed bars $\varnothing 14$ $\mathrm{mm}$ with a spacing of $30 \times 30 \mathrm{~cm}$;

- bottom reinforcement in the form of ribbed bars ø $14 \mathrm{~mm}$ or $16 \mathrm{~mm}$, spaced $15 \times 15 \mathrm{~cm}$.

A characteristic feature of the slab is the use of dowelled joints, which, based on the analysis and calculations performed, are as follows:

- dowels with a diameter of $25 \mathrm{~mm}$ and a length of $60 \mathrm{~cm}$ were used;

- the dowel spacing on the long board edge $(5.0 \mathrm{~m})$ is $62.5 \mathrm{~cm}$, while the dowel spacing on the shorter board edge $(2.5 \mathrm{~m})$ is $55.0 \mathrm{~cm}$.

It should also be added that the design of the dowel joint was developed for the loading of the main shin of the Boeing 737-800, as the design aircraft most frequently used by Polish civil airports. 


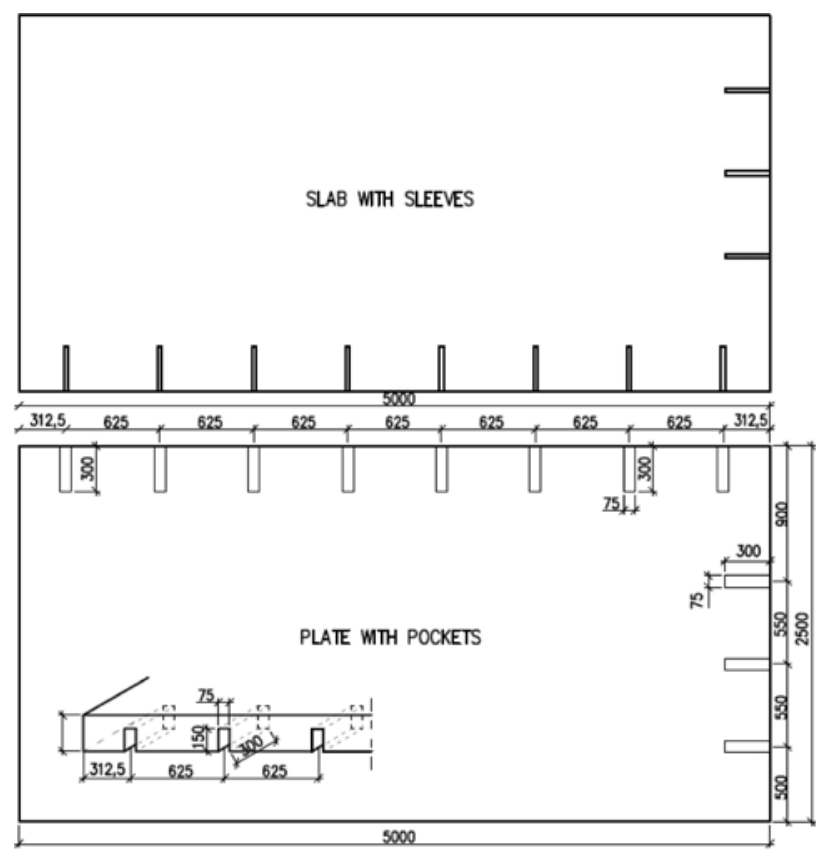

Fig. 5. Prefabricated slabs with dowel joint

\subsection{Description of the hob embedding technology}

The first stage of the airfield pavement repair process with the use of prefabricated slabs is to demolish damaged, old slabs. Each damaged monolithic slab is mechanically dismantled with the use of demolition hammers. The necessary condition for the research experiment is to check whether the foundation, preserved after the demolition of the damaged slab, has an appropriate load capacity, which should correspond to a $20 \mathrm{~cm}$ layer of lean concrete of $\mathrm{C} 8 / 10$ class (Fig. 6). Then the foundation is filled with concrete of $\mathrm{C} 16 / 20$ class and compacted with a heavy vibrating plate. On the substrate prepared in this way, in four or six support points of the prefabricated element, steel sheet washers (pads) are applied to such a height that the prefabricated slab is placed at the same ordinate as the adjacent slabs. Additionally, the washers act as a temporary support for the

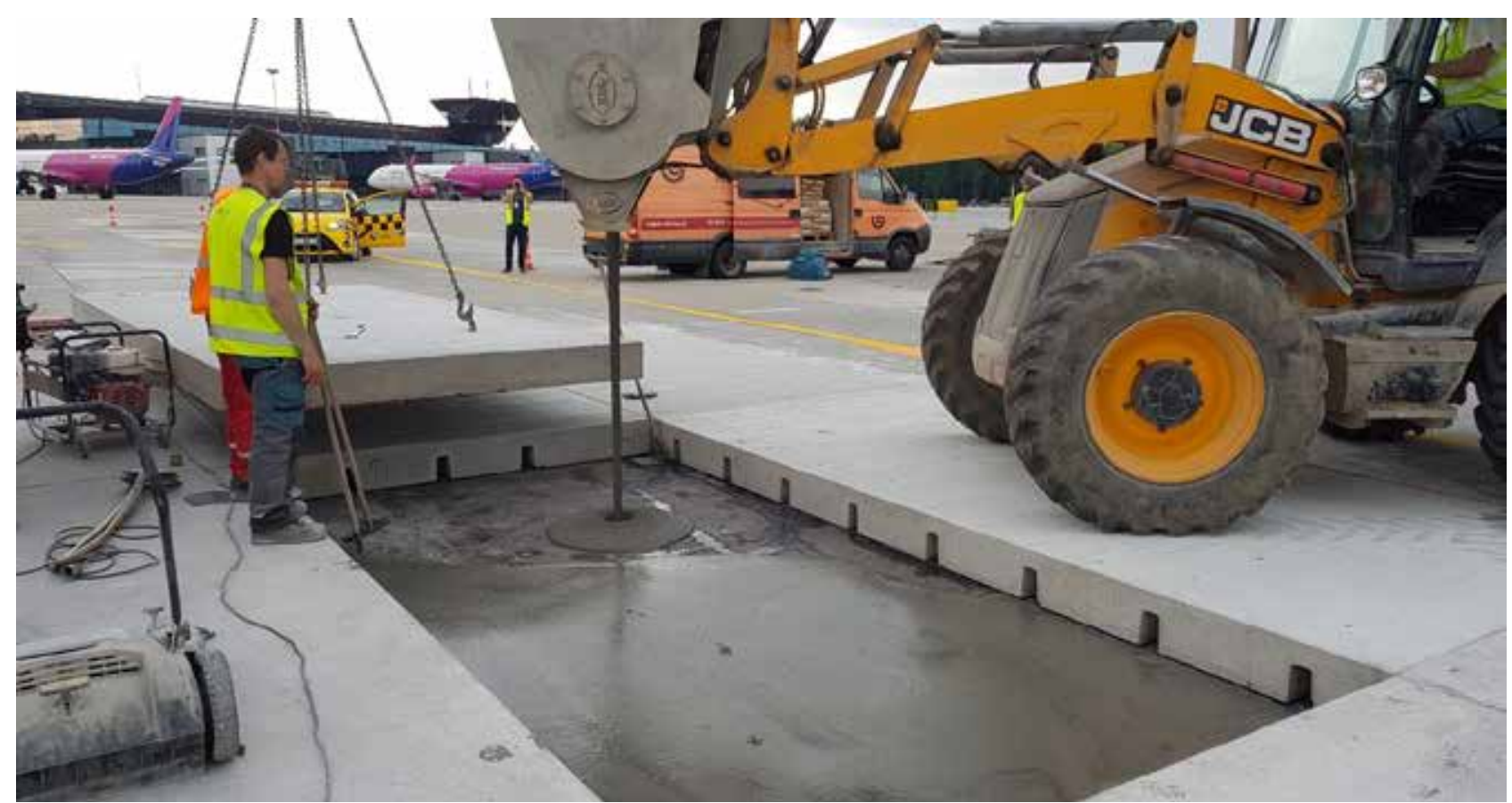

Fig. 6. Installation of a prefabricated concrete slab 
prefabricated element until the mortar achieves the required strength. The next stage of works consists in filling the space between the washers with a nonshrink mortar, which is intended for the repair of concrete and reinforced concrete structures.

Then, using a crane and appropriate slings, the prefabricated slab is installed on previously prepared steel pads. The slab is finally lowered after it is horizontally stabilized and the width of the gaps is maintained. The last stage of assembly works involves injection of a sealing substance under the slab, which is forced under the appropriate pressure through previously prepared holes. Then, after a few days, an expansion cord is installed in the gap between the built-in board and the neighbouring boards and the gap is filled with a sealing compound.

\subsection{Precast concrete slab testing}

\subsubsection{Laboratory tests}

Laboratory tests of the precast concrete slab included the analysis of both the mechanical and physical properties of the concrete. The mechanical properties were determined in the concrete compressive strength and tensile strength test. The physical properties were checked during tests of concrete weight absorption and frost resistance.

\section{Compressive strength}

The compressive strength of concrete was tested in accordance with the PN-EN 12390-3:2019-07 Standard. Concrete tests - Part 3: Compressive strength of test samples [9]. The calculation of the course of concrete strength during the hardening period was made according to the Skramtajew formula [10]:

$$
B_{w n}=B_{w 28} \frac{\lg n}{\lg 28}
$$

where:

$B_{w n}$ - concrete strength after $n$ days from concreting ( $3 \leq n \leq 28$ days);

$B_{w 28}$ - compressive strength of concrete after 28 days; $\lg n$ - the decimal logarithm of the number of days of concrete hardening.

The above formula is appropriate for the concrete hardening temperature at $+15^{\circ} \mathrm{C}$.

Concrete testing for the prefabricated slab was carried out on 12 test samples (cubes) with dimensions of $15 \times 15 \times 15 \mathrm{~cm}$. The test results are presented in Table 1. On the basis of the obtained results, it should be concluded that the cement concrete used for the production of the slab met the requirements for class C35/45 concrete, in accordance with the Defense Standard NO-17-A204: 2015 Airfield pavements - cement concrete pavements - Requirements and test methods [11], because the average value of the compressive strength was $50.2 \mathrm{MPa}$.

Table 1. Results of concrete compressive strength

\begin{tabular}{|c|c|c|c|}
\hline $\begin{array}{c}\text { Sample } \\
\text { number }\end{array}$ & $\begin{array}{c}\text { Volume density } \\
{\left[\mathbf{k g} / \mathbf{m}^{3}\right]}\end{array}$ & $\begin{array}{c}\text { Force } \\
{[\mathbf{k N}]}\end{array}$ & $\begin{array}{c}\text { Compressive strength } \\
{[\mathrm{MPa}]}\end{array}$ \\
\hline 1 & 2407 & 1078 & 47.9 \\
\hline 2 & 2319 & 1143 & 50.8 \\
\hline 3 & 2365 & 1173 & 52.1 \\
\hline 4 & 2313 & 1145 & 50.9 \\
\hline 5 & 2405 & 1190 & 52.9 \\
\hline 6 & 2320 & 1116 & 49.6 \\
\hline 7 & 2331 & 1016 & 45.2 \\
\hline 8 & 2321 & 1184 & 52.6 \\
\hline 9 & 2389 & 1045 & 46.4 \\
\hline 10 & 2318 & 1101 & 48.9 \\
\hline 11 & 2347 & 1150 & 51.1 \\
\hline 12 & 2323 & 1222 & 54.3 \\
\hline Average value: & 2347 & 1130 & $\mathbf{5 0 . 2}$ \\
\hline & & & \\
\hline
\end{tabular}

\section{Bending tensile strength}

The bending tensile properties of concrete were tested in accordance with the PN-EN 12390-5: 201908 Standard. Concrete tests - Part 5: Bending strength of test specimens [12]. The calculations were made according to the following formula:

$$
f_{c f}=\frac{P \times l}{d_{1} \times d_{2}^{2}}
$$

where:

$f_{c f}$ - concrete tensile strength marked according to standards [MPa];

$P$ - maximum loading force $[\mathrm{kN}]$;

$l$-spacing of supports (supporting rollers) $[\mathrm{mm}]$; $d_{1}, d_{2}$ - transverse dimensions of the tested beam [mm].

The test was carried out on 8 beams with dimensions of $70 \times 15 \times 15 \mathrm{~cm}$, applying the load with one concentrated force (centrically). The average value 
of the strength obtained on the basis of the tests was 5.79 $\mathrm{MPa}$ (standard deviation 0.24 MPa). Based on the tests performed, it should be confirmed that the prefabricated slab is made of cement concrete that meets the requirements for class $\mathrm{C} 35 / 45$, according to the Defense Standard [11].

\section{Concrete water absorption test}

The water absorbability of concrete is a physical feature that determines the ratio of the mass of water that the concrete is able to absorb to its dry mass. The test was performed in accordance with the PN88/B-06250 Standard Concrete [13].

In the experiment, the water absorption test was carried out on six cubic samples, each of which had dimensions of $15 \times 15 \times 15 \mathrm{~cm}$. Table 2 presents the results of the obtained measurements. The average value of concrete water absorption was $3.9 \%$. On the basis of this test, it can be confirmed that the cement concrete met the standard requirements because its water absorption did not exceed $5 \%$ of the limit value, according to the Defense Standard [11].

Table 2. Concrete water absorption test results

\begin{tabular}{|c|c|c|c|}
\hline \multirow{2}{*}{$\begin{array}{c}\text { Sample } \\
\text { number }\end{array}$} & \multicolumn{2}{|c|}{ Sample weight [g] } & \multirow{2}{*}{$\begin{array}{c}\text { Absorption } \\
\text { [\%] }\end{array}$} \\
\cline { 2 - 4 } & saturated & dry & 3.9 \\
\hline 1 & 7828 & 7536 & 3.8 \\
\hline 2 & 7983 & 7693 & 4.0 \\
\hline 3 & 7831 & 7531 & 3.9 \\
\hline 4 & 7834 & 7540 & 3.8 \\
\hline 5 & 7824 & 7539 & 4.0 \\
\hline 6 & 7920 & 7615 & $\mathbf{3 . 9}$ \\
\hline Average value & 7870 & 7576 & \\
\hline
\end{tabular}

\section{Concrete frost resistance test}

On the basis of the PN-B-06265 Standard, which is the national supplement to the PN-EN 206-1 Concrete [14]. Standard, a concrete frost resistance test was performed. The test method consists in verifying the designed degree of frost resistance (F) of concrete, which corresponds to the index $(\mathrm{N})$, which determines the number of expected years of use of the structure.

The test was performed on 12 cubic samples, each measuring $15 \times 15 \times 15 \mathrm{~cm}$. The number of freezethaw cycles was 200 .

The test results are presented in Table 3 indicate that the cement concrete subjected to the assessment met the requirements for the frost resistance degree
F200. In accordance with the applicable standard, the weight loss of samples after the test was less than 5\%, and the average decrease in compressive strength did not exceed $20 \%$.

Table 3. The results of concrete frost resistance tests

\begin{tabular}{|c|c|c|c|c|c|}
\hline \multirow{2}{*}{$\begin{array}{l}\text { Sample } \\
\text { number }\end{array}$} & \multicolumn{2}{|c|}{ Sample weight [g] } & \multirow{2}{*}{$\begin{array}{c}\text { Loss of } \\
\text { weight } \\
\qquad G \\
{[\%]}\end{array}$} & \multirow{2}{*}{$\begin{array}{c}\text { Strength } \\
\boldsymbol{R}_{\boldsymbol{i}} \\
{[\mathrm{MPa}]}\end{array}$} & \multirow{2}{*}{$\begin{array}{c}\text { Decrease } \\
\text { Endurance } \\
\Delta \operatorname{Ri}[\%]\end{array}$} \\
\hline & $\begin{array}{c}\text { before } \\
\text { research }\end{array}$ & $\begin{array}{l}\text { after } \\
\text { study }\end{array}$ & & & \\
\hline 1 & 7940 & 7925 & \multirow{6}{*}{0.22} & 51.9 & \multirow{12}{*}{15.3} \\
\hline 2 & 7815 & 7795 & & 46.4 & \\
\hline 3 & 7860 & 7840 & & 49.2 & \\
\hline 4 & 7800 & 7775 & & 45.8 & \\
\hline 5 & 7930 & 7915 & & 52.1 & \\
\hline 6 & 7925 & 7915 & & 52.0 & \\
\hline 7 & \multirow{6}{*}{\multicolumn{3}{|c|}{$\begin{array}{c}\text { samples-witnes } \\
60.1 \\
56.2 \\
61.4 \\
58.1 \\
59.7\end{array}$}} & 55.7 & \\
\hline 8 & & & & & \\
\hline 9 & & & & & \\
\hline 10 & & & & & \\
\hline 11 & & & & & \\
\hline 12 & & & & & \\
\hline
\end{tabular}

\subsubsection{Field tests for the assessment of pavement load capacity}

The research experience consisting in the incorporation of a prefabricated concrete slab was carried out on the DK-Z4 taxiway at one of the airports in Poland. The taxiway had plates with numerous damage, which, according to the diagnostics specified in Chapter 3, required immediate corrective action. The place of installation prefabricated slab is shown in Figure 7.

Tests of the load-bearing capacity of precast concrete slabs were carried out using the HWD (Heavy Weight Deflectometer), in accordance with the Defense Standard NO-17-A500: 2016 Airfield and road pavements. Load capacity tests [15]. The tests were carried out both on the existing slabs (before replacement) and on new, embedded precast concrete slabs.

The assessed airport pavement of the taxiway had the following structural system:

- cement concrete pavement, class B-40, thickness $25.0 \mathrm{~cm}$;

- bituminized aggregate sliding layer, thickness $3.0 \mathrm{~cm}$;

- upper layer of asphalt concrete foundation, thickness $10.0 \mathrm{~cm}$;

- ARMAPAL GL $100 \times 100$ anti-crack reinforcing mesh; 


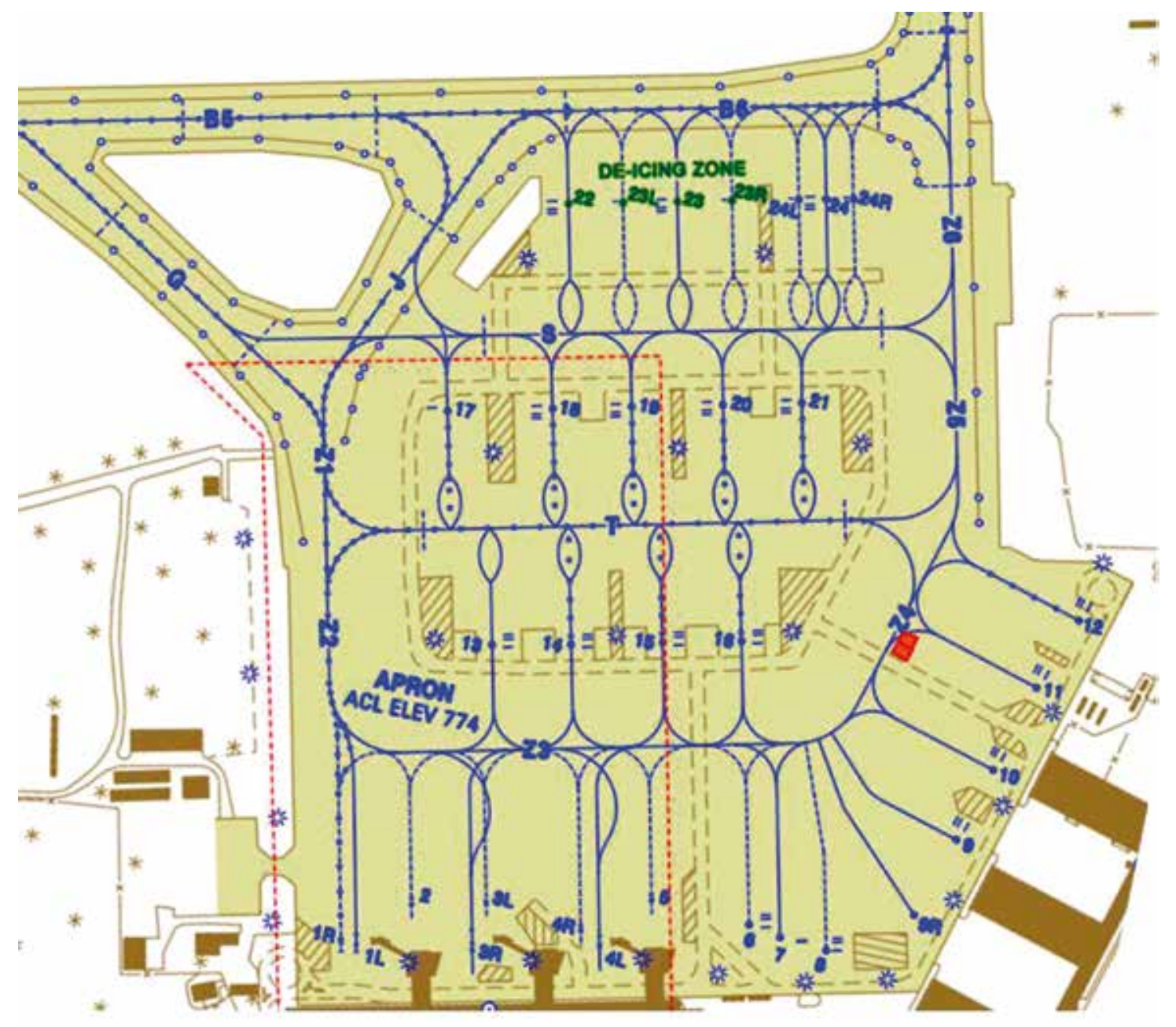

slabs intended for demolition

Fig. 7. The airport apron with the locations of damaged plates marked

- lower layer class B-25 cement concrete foundation, thickness $24.0 \mathrm{~cm}$;

- drainage layer of medium gravel, thickness 15.0-30.0 cm;

- REHAU-FILTRAM 1B1 drainage mat with double-sided geotextile;

- mineral soil embankment - permeable, with good compactability, thickness $75.0 \mathrm{~cm}$ including the bedding;

- the existing subsoil (according to geological research).

The Boeing 737-800 computing aircraft was adopted for research purposes. It is an aircraft most often used at civil airports in Poland. The basic parameters of the load capacity state of the aircraft, including the ACN indexes corresponding to the ground load category (A, B, C, D - see Table 7), are presented in Table 4.
Table 4. Basic parameters of the adopted aircraft type

\begin{tabular}{|c|c|c|c|c|c|c|c|c|c|}
\hline & & \multicolumn{7}{|c|}{ Substrate load capacity category } \\
\cline { 3 - 9 } Aircraft type & $\begin{array}{c}\text { Mass } \\
{[\mathrm{kg}]}\end{array}$ & \multicolumn{3}{|c|}{ Rigid pavement } & \multicolumn{6}{c|}{ Flexible pavement } \\
\cline { 3 - 9 } & & A & B & C & D & A & B & C & D \\
\hline $\begin{array}{c}\text { B 737-800 } \\
\text { ACN } \\
\text { (aircraft } \\
\text { classification } \\
\text { number) }\end{array}$ & 49242 & 49 & 52 & 54 & 56 & 43 & 45 & 50 & 55 \\
\cline { 2 - 10 } & 41413 & 23 & 24 & 25 & 27 & 20 & 21 & 22 & 26 \\
\hline
\end{tabular}

Based on the results of the field tests, the calculation model for the assessed structure of the airport pavement was determined, as shown in Figure 8. 


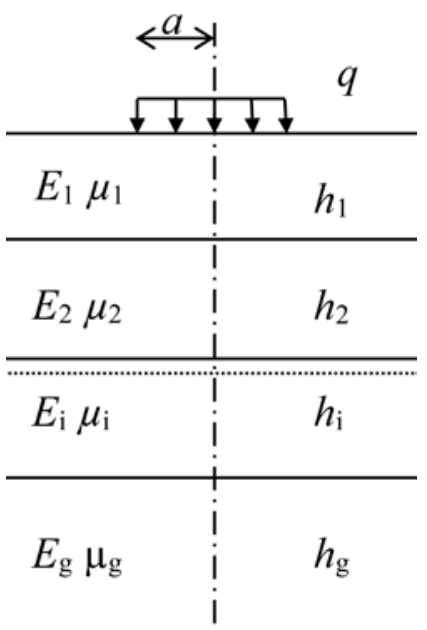

where:

$E$ - layer modulus;

$\mu$ - layer Poisson's ratio;

$h$ - layer thickness;

$q$ - load on the pavement;

$a$-radius of the load on the pavement

Fig. 8. Calculation model of the assessed pavement structure

Measurements of elastic deflections of the plates were measured in the places indicated in Figure 9.

TAXIWAY Z - 4

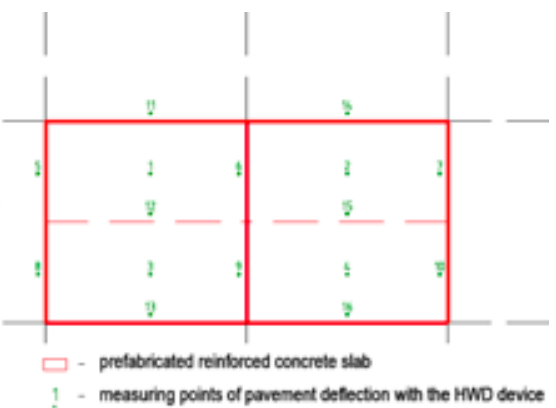

Fig. 9. Plan of deflection measurements on the assessed prefabricated slab

The results of the elastic deflection tests, both on the existing slabs and on the newly built-in prefabricated slabs, are presented in Tables 5 and 6 . The replacement modules were calculated according to the following formula:

$$
E_{z}=\frac{2 q r}{d}
$$

where:

$E_{z}$ - construction replacement module [MPa],

$q$ - stress under the pressure plate [MPa],

$r$-pressure plate radius [mm],

$d$-elastic deflection in the axis of the pressure plate [mm].
Table 5. The results of the plate elastic deflection test (before replacement)

\begin{tabular}{|c|c|c|c|c|}
\hline $\begin{array}{l}\text { Measurement } \\
\text { point }\end{array}$ & $\begin{array}{c}\text { Stress } \\
\text { under } \\
\text { the slab } \\
{[\mathrm{kPa}]}\end{array}$ & $\begin{array}{c}\text { Drop force } \\
{[\mathrm{kN}]}\end{array}$ & $\begin{array}{c}\text { Deflection } \\
{[\mu \mathrm{m}]}\end{array}$ & $\begin{array}{c}\text { Replacement } \\
\text { module } \\
\text { [MPa] }\end{array}$ \\
\hline 1 & 1247.00 & 198.33 & 370.60 & 1514.17 \\
\hline 2 & 1249.00 & 198.64 & 285.40 & 1969.34 \\
\hline 3 & 1245.00 & 197.98 & 424.00 & 1321.34 \\
\hline 4 & 1247.00 & 198.33 & 304.90 & 1840.44 \\
\hline Average & 1247.00 & 198.32 & 346.23 & 1661.32 \\
\hline $\begin{array}{l}\text { Standard } \\
\text { deviation }[\mu \mathrm{m}]\end{array}$ & 1.63 & 0.27 & 63.38 & 296.76 \\
\hline $\begin{array}{l}\text { Coefficient } \\
\text { of variation [\%] }\end{array}$ & 0.13 & 0.14 & 18.31 & 17.86 \\
\hline
\end{tabular}

Table 6. The results of the plate elastic deflection tests (after replacement)

\begin{tabular}{|c|c|c|c|c|}
\hline $\begin{array}{l}\text { Measurement } \\
\text { point }\end{array}$ & $\begin{array}{c}\text { Stress } \\
\text { under } \\
\text { the slab } \\
{[\mathrm{kPa}]}\end{array}$ & $\begin{array}{c}\text { Drop force } \\
\text { [kN] }\end{array}$ & 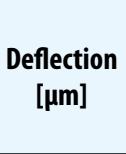 & $\begin{array}{c}\text { Replacement } \\
\text { module } \\
\text { [MPa] }\end{array}$ \\
\hline 1 & 1250.00 & 198.72 & 139.50 & 4032.26 \\
\hline 2 & 1243.00 & 197.61 & 141.40 & 3955.80 \\
\hline 3 & 1242.00 & 197.45 & 145.70 & 3835.96 \\
\hline 4 & 1246.00 & 198.22 & 148.40 & 3778.30 \\
\hline Average & 1245.25 & 198.00 & 143.75 & 3900.58 \\
\hline $\begin{array}{l}\text { Standard } \\
\text { deviation }[\mu \mathrm{m}]\end{array}$ & 3.59 & 0.58 & 4.04 & 114.77 \\
\hline $\begin{array}{l}\text { Coefficient } \\
\text { of variation [\%] }\end{array}$ & 0.29 & 0.29 & 2.81 & 2.94 \\
\hline
\end{tabular}

As shown the comparative studies, the average deflection value measured on new prefabricated slabs $(\mathbf{1 4 3 . 7 5} \mu \mathrm{m})$ is $59 \%$ lower than the average deflection value measured on the existing slabs. The average value of the calculated equivalent module of the pavement structure with prefabricated slabs $\mathbf{( 3 9 0 0 . 5 8}$ MPa) is $135 \%$ higher than the replacement module determined for the reference structure.

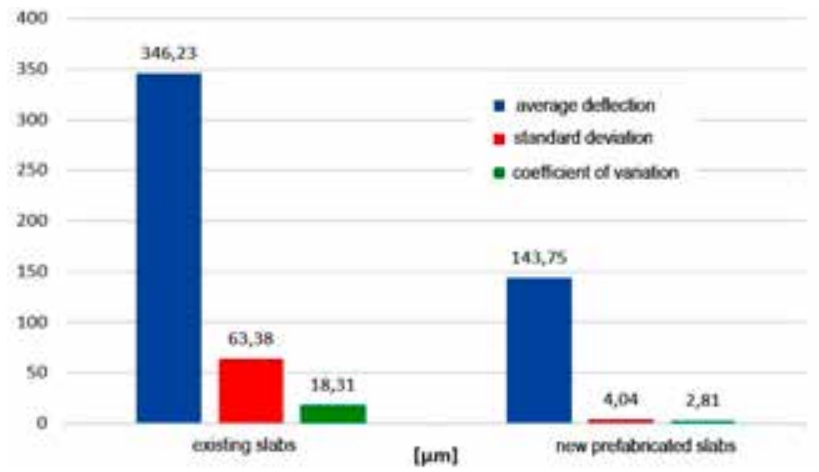

Fig. 10. Comparison of deflection values for the existing slabs and the new prefabricated elements 
Table 7. Interpretation of ACN-PCN method indications [16]

\begin{tabular}{|c|c|c|c|c|c|}
\hline 1 & Dimensionless $\mathrm{PCN}$ number & & & & \\
\hline \multirow{2}{*}{2} & \multirow{2}{*}{ Type of surface } & $\mathbf{R}$ & \multicolumn{3}{|l|}{ rigid } \\
\hline & & $\mathbf{F}$ & \multicolumn{3}{|l|}{ flexible } \\
\hline \multirow{4}{*}{3} & \multirow{4}{*}{$\begin{array}{l}\text { Soil category } \\
\text { (for rigid pavements - } k \text {, } \\
\text { for flexible pavements - CBR) }\end{array}$} & A & high strength & $\mathrm{k}>120 \mathrm{MN} / \mathrm{m}^{3}$ & $C B R>13$ \\
\hline & & B & medium strength & $60-120 \mathrm{MN} / \mathrm{m}^{3}$ & $8-13$ \\
\hline & & C & low strength & $25-60 \mathrm{MN} / \mathrm{m}^{3}$ & $4-8$ \\
\hline & & D & ultra low strength & $\mathrm{k}<25 \mathrm{MN} / \mathrm{m}^{3}$ & $C B R<4$ \\
\hline \multirow{4}{*}{4} & \multirow{4}{*}{ Aircraft tire pressure allowed } & W & \multicolumn{3}{|l|}{ unlimited } \\
\hline & & $x$ & \multicolumn{3}{|l|}{ high to $1.5 \mathrm{MPa}$} \\
\hline & & $Y$ & \multicolumn{3}{|l|}{ medium to $1.0 \mathrm{MPa}$} \\
\hline & & $\mathbf{Z}$ & \multicolumn{3}{|l|}{ low to $0.5 \mathrm{MPa}$} \\
\hline \multirow{2}{*}{5} & \multirow{2}{*}{ Assessment method } & $\mathbf{T}$ & \multicolumn{3}{|c|}{ indicates technical evaluation } \\
\hline & & $\mathbf{U}$ & \multicolumn{3}{|c|}{ indicates usage - a physical testing regime } \\
\hline
\end{tabular}

Taking into account the results of the elastic deflections measured on the existing prefabricated slabs, the deflection bowl was determined, followed by the stresses in the airport pavement. As a result of further analysis, the current load capacity index of the PCN was determined and the allowable total number of flight operations for the adopted calculation aircraft, determined for the existing plates.

In accordance with the assumptions of the International Civil Aviation Organization ICAO, the classification number of PCN expresses the load capacity of the airport pavement. It is equivalent to $1 / 500$ of the allowable load (expressed in kg of mass) applied to the pavement via a single wheel with the standard pressure of $1.25 \mathrm{MPa}[8,16]$. In the ACNPCN (Table 7) method, the pavement load capacity is described by a group of symbols characterizing individual parameters of the structure and informing about the method of determining the PCN number [18-20].

In order to calculate the allowable number of loads, the stresses in the pavement for the adopted calculation model should be compared with the allowable stresses, which are determined using the stress criterion taking into account the repeatability of loads $[16,17]$. Then compare the PCN of the pavement under test with the ACN number of the design aircraft. The analysis carried out in this way will allow to determine whether an aircraft can safely operate on a test surface and what will be the forecast, allowable number of air operations.

The designated total number of air operations is specified in Tables 8 and 9.
Table 8. The load capacity results for the Boeing 737-800 design airplane for the existing plates

\begin{tabular}{|c|c|c|}
\hline Functional element of the airport & $\begin{array}{c}\text { Indicator } \\
\text { load capacity } \\
\text { PCN }\end{array}$ & $\begin{array}{c}\text { Total number } \\
\text { air operations }\end{array}$ \\
\hline Taxiway Z4 (before change) & $52 / \mathrm{R} / \mathrm{B} / \mathrm{W} / \mathrm{T}$ & 145000 \\
\hline
\end{tabular}

According to the same operation algorithm, taking into account the determined PCN load index equal to 52 , the allowable total number of flight operations for the structural system with new prefabricated slabs was determined, as shown in Table 9.

Table 9. The results of the load capacity for the Boeing 737800 design airplane for prefabricated slabs

\begin{tabular}{|c|c|c|}
\hline Functional element of the airport & $\begin{array}{c}\text { Indicator load } \\
\text { capacity } \\
\text { PCN }\end{array}$ & $\begin{array}{c}\text { Total number air } \\
\text { operations }\end{array}$ \\
\hline Taxiway Z4 (prefabricated slabs) & $52 / \mathrm{R} / \mathrm{B} / \mathrm{W} / \mathrm{T}$ & 255000 \\
\hline
\end{tabular}

The carried out load capacity analysis proves that the newly applied technology of the precast concrete slab significantly increases the pavement load capacity parameter.

As a consequence, the number of permissible air operations on existing plates in relation to the number of operations on newly built prefabricated slabs increased by $76 \%$.

Additionally, during the field tests, the cooperation of adjacent plates was analyzed. The aim of the study was to determine the level of plate cooperation after the use of dowelling technology. 
For this purpose, the load transfer coefficient was determined, which is the main factor determining the cooperation of the plates. We calculate this indicator according to the formula:

$$
J=\frac{U_{n}}{U_{o}} \times 100
$$

where:

$J-$ load transfer factor [\%];

$U_{n}$ - deflection on an unloaded plate;

$U_{o}-$ deflection on the loaded plate.

During the measurements with the HWD device, three load drops were made at each designated measurement point. The sensors in the HWD device were arranged as shown in Figure 11, however, only sensors 2 and 3 were taken into account for testing the cooperation of adjacent plates.

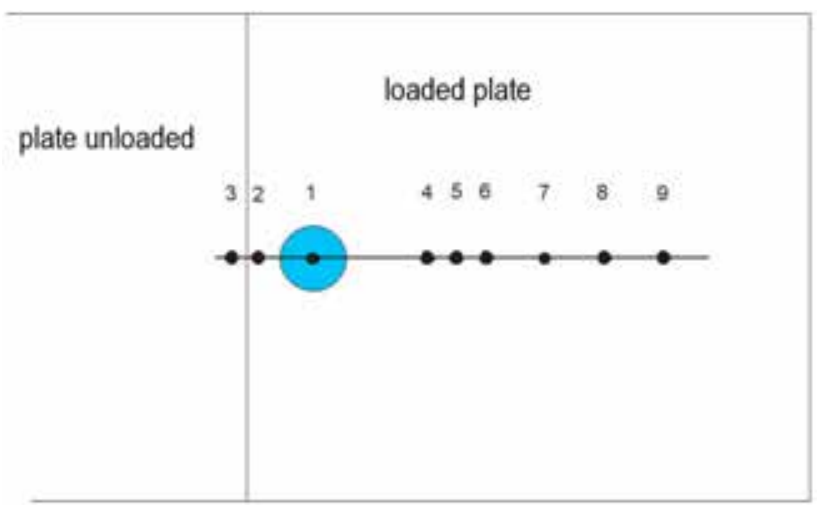

Fig. 11. Arrangement of the HWD sensors

Based on the obtained results presented in Table 10 , it was found that the cooperation of the plates is ensured at a very high level, as the determined average value of the load transfer coefficient was over $90 \%$.

\section{CONCLUSIONS}

The data published by agencies related to air traffic research, including the Civil Aviation Authority responsible for statistics on Poland, prove that air traffic is currently one of the most developing modes of transport. The growing air transport also means the increased impact of aircraft on airport surfaces.

Airport pavements in Poland are very often made of cement concrete, due to its features such as resistance to de-icing agents, frost resistance or high mechanical and operational parameters. Despite so many indisputable advantages of concrete pavements, they are also subject to gradual damage and, consequently, degradation, which can cause a threat to the safety of air operations by aircraft.

Considering the above, it has become necessary to search for new repair technologies that will allow the reconstruction of damaged pavements, but within a strictly defined time regime.

Such a technology is the proposed prefabricated concrete slab with the dowelling option. As the research presented in the article showed, the method used allows not only to quickly and effectively restore the load-bearing capacity of degraded slabs, but even to significantly increase the load-bearing capacity of the pavement. In addition, the use of connecting adjacent panels with dowels creates a new design quality that increases the spatial stiffness of the entire functional element. As a consequence, the loads generated by aircraft on concrete slabs are evenly distributed, thus preventing premature damage to the slab in use.

Table 10. The results of the cooperation of prefabricated panels

\begin{tabular}{|c|c|c|c|c|c|}
\hline Measurement point & $\begin{array}{l}\text { Stress under } \\
\text { the slab [kPa] }\end{array}$ & Drop force $[k N]$ & $\begin{array}{c}\text { Deflection } \\
\text { of sensor } 2[\mu \mathrm{m}]\end{array}$ & $\begin{array}{c}\text { Deflection } \\
\text { of sensor } 3[\mu \mathrm{m}]\end{array}$ & $\mathrm{J}[\%]$ \\
\hline 6 (only prefabricated slab) & 1241.00 & 197.34 & 159.60 & 145.20 & 91.0 \\
\hline 9 (only prefabricated slab) & 1240.00 & 197.21 & 155.30 & 136.30 & 87.8 \\
\hline 12 (only prefabricated slab) & 1243.00 & 197.69 & 122.50 & 112.80 & 92.1 \\
\hline 15 (only prefabricated slab) & 1243.00 & 197.61 & 118.60 & 107.40 & 90.6 \\
\hline Average & 1241.75 & 197.46 & 139.00 & 125.43 & 90.3 \\
\hline
\end{tabular}




\section{REFERENCES}

[1] Nita P., Construction and maintenance of airport pavements, Wydawnictwo Komunikacji i Łączności, Warszawa 2008.

[2] Shiraz Tayabji, Precast Concrete Pavement Innovations, Performance and Best Practices, Conference Paper, September 2014.

[3] Poświata A., Wesołowski M., Kowalska D., Modern concrete airport pavements in Poland - selected issues, Konferencja Dni Betonu, 2014.

[4] Poświata A., Wesołowski M., Airfield pavements as an element of critical infrastructure in the airport safety management process, „Przegląd komunikacyjny” 11/2017.

[5] Nita P., Wesołowski M., Selection of parameters and indices characterising the degradation degree of slabs constituting elements of airport pavements made from cement concrete, based on the data obtained from exploited facilities, ITWL, Warsaw 2016.

[6] Nita P., Concrete airport pavements, „Theory and Structural Dimensioning”, Wydawnictwo Instytutu Technicznego Wojsk Lotniczych, Warszawa 2005.

[7] Wesołowski M., Poświata A., Jakubek M., Fast technologies for restoring the technical condition of damaged cement concrete airfield pavements, IX Konferencja Dni Betonu, Wisła 2016.

[8] Wesołowski M., Świerzewski B., Kowalewska A., Jakubek M., Prefabricated airport slab - an effective technology for restoring the load-bearing capacity of degraded airfield pavements made of cement concrete, X Konferencja Dni Betonu, Wisła 2018.

[9] PN-EN 12390-3: 2019-07 Concrete tests - Part 3: Compressive strength of test samples.

[10] Skramtajew B.G., Determining concrete strength for control of concrete structures, Journal of ACI, Vol. 34, 1938, p. 285.

[11] Defense Standard NO-17-A204: 2015 Airfield pavements - cement concrete pavements - Requirements and test methods.

[12] PN-EN 12390-5: 2019-08 Concrete tests - Part 5: Bending strength of test specimens.

[13] PN-88/B-06250 Normal Concrete.

[14] PN-B-06265:2018-10 Concrete, Requirements, properties, production and compliance, National complement PN-EN 206+A1:2016-12.

[15] Defense Standard NO-17-A500:2016 Airport and road surfaces. Load capacity tests.

[16] Wesołowski M., Blacha K., Evaluation of the carrying capacity of airport pavements using the ACN-PCN method. Prace Naukowe ITWL, 35, 2014. pp. 5-21.

[17] Wesołowski M., Blacha K., Iwanowski P., Analysis of Load Bearing Capacity of Cement Concrete Airfield Pavement's Construction in Relation to its' Changes of Physico-Mechanical Parameters, IOP Conference Series: Materials Science and Engineering, Vol. 603, Issue 5, 2019.

[18] Wesołowski M., Iwanowski P., APCI Evaluation Method for Cement Concrete Airport Pavements in the Scope of Air Operation Safety and Air Transport Participants Life, „International Journal of Environmental Research and Public Health", Vol. 17, Issue 5, 1663, 2020.

[19] Annex 14 ICAO to the Convention on International Civil Aviation, Airports Volume I - Design and operation of airports, wydanie 7, lipiec 2016.

[20] Aerodrome Design Manual Part 3, Pavements, ICAO, Doc-9157-AN/901.

[21] ICAO Standard 9137-AN/898 Part 2 Airport Service Manual.

[22] Linek M., Wesołowski M., Selected aspects of evaluating the technical condition of concrete airport pavements in terms of service life, Structure \& Environment, 11 (4), pp. 265-277

\section{Acknowledgments:}

The works were financed by the REKMA Sp. z o.o. 32-080

Brzezie, ul. Szlachecka 7

\section{Podziękowania:}

Prace zostały sfinansowane przez REKMA Sp. z o.o. 32-080 Brzezie, ul. Szlachecka 7 